\section{簡易同定キットによる魚類病原性 連鎖球菌の迅速同定}

\author{
飯田貴次・浜崎恒二・若林久嗣 \\ (東京大学農学部)
}

日本における魚類連鎖球菌症はブリ ${ }^{1-3) ， ウ ナ キ ゙ 4) ， ア ~}$ ユ ${ }^{5)}$ ，テラピプなどの多くの魚種で発生し，産業的に 大きな問題となっている。しかし，これらの魚種から分 離される連鎖球菌は多種にわたり，さらに，同じ魚種か ら異なる菌種が分離されたり ${ }^{1-3)}$ ，同じ菌種が異なる魚 種から分離されたりし4), 連鎖球菌症の正しい診断, 病 原菌の同定を繁雃なものにしている。そこで，近年，連 鎖球菌の同定に使用されている市販のキットを用いて魚 類病原性連鎖球菌の簡易迅速同定について検討した。

\section{材料および方法}

供試菌株を表 1 亿示した。これらの菌株は, 従来の方 法により今まで報告されている菌種に同定された性状の 明らかなものである。市肘の簡易同定キットには, 20 項 目の生化学的テストと溶血性（表 2) を組合せて標準化 した連鎖球菌用簡易同定キット，アピストレップ 20 (ア スカ純薬)を用いた。菌の培養, プレートへの菌の接 種，判定はキットの使用方法に従った。すなわち，馬お よび羊血液寒天培地で溶血性を判定した後, 羊血液加 (5\%) コロンビア寒天培地に菌を接種し， $37^{\circ} \mathrm{C} て ゙ ~ 24$ 時 間嫌気培養する。培養後, マクファーランド濁度 4 以上 になるように滅菌精製水に浮遊させ，プレートに接種す る。 $37^{\circ} \mathrm{C}$ で培養し， 4 時間後および 24 時間後に判定表

表 1. 実験に使用した連鎖球菌の由来

菌株番号

\begin{tabular}{|c|c|}
\hline \multicolumn{2}{|l|}{ 魚類由来菌株 } \\
\hline \multicolumn{2}{|l|}{ ブリ由来 } \\
\hline$\alpha$ 溶血性 $^{1)}$ & $135,136,137,138,139,142$ \\
\hline$\beta$ 溶血性 $^{2)}$ & 716 \\
\hline 非溶血性 ${ }^{3)}$ & $717,718,719,720$ \\
\hline ウナギ由来 ${ }^{4)}$ & 362,363 \\
\hline テラピア由来 ${ }^{5)}$ & $629,630,631,632,633,634$ \\
\hline アユ由来 ${ }^{8)}$ & 341,342 \\
\hline \multicolumn{2}{|l|}{ 対照菌株 } \\
\hline E. facealis & IAM 10067, IAM 1007 \\
\hline E. faecium & IAM 1262 (ATCC 8043) \\
\hline S. agalactiae & IID 1626 \\
\hline
\end{tabular}

1 B)：参考文献番号
表 2. アピストレップ 20 のテスト項目

\begin{tabular}{|c|c|}
\hline テスト項目 & 得 点 \\
\hline $\begin{array}{l}\text { 一P テスト } \\
\text { 一馬尿酸塩加水分解 } \\
\text { 一エスクン加水分解 }\end{array}$ & $\begin{array}{l}1 \\
2 \\
4\end{array}$ \\
\hline $\begin{array}{l}\text { 一ピロリドニルアリルアミダーゼ } \\
\text { - } \alpha \text {-ガラクトシダーゼ } \\
\text { - } \beta \text {-グルクロニダーゼ }\end{array}$ & $\begin{array}{l}1 \\
2 \\
4\end{array}$ \\
\hline $\begin{array}{l}\text { 一-カーガラクトシダーゼ } \\
\text { 一アルカリフォスファターゼ } \\
\text { 一ロイシンアリルアミダーゼ }\end{array}$ & $\begin{array}{l}1 \\
2 \\
4\end{array}$ \\
\hline $\begin{array}{l}\text { 一アルギニン脱水素 } \\
\text { 一酸産生：リボース } \\
\text { 一 }\end{array}$ & $\begin{array}{l}1 \\
2 \\
4\end{array}$ \\
\hline$\left[\begin{array}{l}\text { マンニトール } \\
\text { ソルビット } \\
\text { 乳糖 }\end{array}\right.$ & $\begin{array}{l}1 \\
2 \\
4\end{array}$ \\
\hline 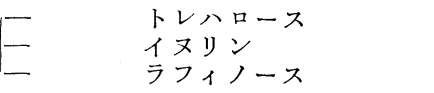 & $\begin{array}{l}1 \\
2 \\
4\end{array}$ \\
\hline$\left[\begin{array}{l}\text { F゙ンプン } \\
\text { - } \beta \text {-溶血性 }\end{array}\right.$ & $\begin{array}{l}1 \\
2 \\
4\end{array}$ \\
\hline
\end{tabular}

に従い結果を判定, 数值プロファイルに変換する。数值 プロファイルは以下の様に求める。すなわち, 表 2 のテ ストを上から 3 つずつのグループに分け，陽性反応に対 してはそれぞれの得点を与え, グループ毎にその得点を 合計する。1 つのグループの得点合計は 0 から 7 までの いずれかの值になり,さらに，テスト全体の結果は表 2 に示したグループ毎の上から順の 7 桁の数值になる。

\section{結果および考察}

今回の実験において 4 時間後の判定では結果にバラッ キが大きく，そこで 4 時間後には判定を行わず，全て 24 時間後の結果を採用した。アピストレップ 20 による同 定の結果, 対照として用いた Streptococcus agalactiae は同種の菌に同定されたが, Enterococcus faecalis, E. faecium がそれぞれ E. faecium, E. durans に同定さ れ，対照菌株あるいはこのキットに問題がなかった訳で はないが，結果は安定しており数值プロファイルによる 菌種判定には問題はないものと考号られた。魚類由来連 鎖球菌に执いては (表 3), ブリ由来 $\alpha$ 溶血性菌, テラ ピア由来菌，アユ由来菌は，それぞれ，異なる菌株にお いても同一の数值プロファイルが得られ，その数值はそ れぞれの菌種の固有のプロファイルと考兄られた。ブリ 由来溶血性菌の数值プロファイル (5143010) はインデッ クス内に存在し，そこには同定結果として 2 つ菌種が 記載されているものの, 鑑別精度は低く, この数值はブ リ $\alpha$ 由来溶血性菌固有のものとして差し支えないものと 
表 3. 魚類由来連鎖球菌のアピストレップ 20 により得られた数值プロファイル

\begin{tabular}{|c|c|c|c|c|c|}
\hline \multirow{2}{*}{ 菌株（頻度） } & \multirow{2}{*}{ 数值プロファイ } & \multicolumn{4}{|c|}{ 得られた数值プロファイルからのインデックスによる同定結果 } \\
\hline & & 分類群*1 & 同定確率 & $\mathrm{T}$ インデックス & 鑑別精度 \\
\hline \multicolumn{6}{|l|}{ ブリ由来 } \\
\hline \multicolumn{6}{|l|}{$\alpha$ 溶血性 } \\
\hline \multicolumn{6}{|c|}{$135(2 / 2), 136(5 / 5), 137(2 / 2), 138(1 / 1), 139(2 / 2), 142(2 / 2)$} \\
\hline & 5143010 & E. durans*2 & 62.4 & 0.72 & Low discrimination \\
\hline \multicolumn{6}{|l|}{$\beta$ 溶血性 } \\
\hline $716(2 / 5)$ & 4162015 & 該当分類群なし & & & \\
\hline$(1 / 5)$ & 4162017 & 該当分類群なし & & & \\
\hline$(1 / 5)$ & 4162115 & 該当分類群なし & & & \\
\hline$(1 / 5)$ & 4163115 & 該当分類群なし & & & \\
\hline \multicolumn{6}{|l|}{ 非溶血性 } \\
\hline $717(4 / 5)$ & 1060000 & G. haemolysans*2 & 79.8 & 0.95 & Low discrimination \\
\hline$(1 / 5)$ & 1061000 & S. milleri & 97.7 & 0.72 & Good identification \\
\hline \multicolumn{6}{|c|}{$718(1 / 1), 719(2 / 2), 720(2 / 2)$} \\
\hline & 1060000 & G. haemolysans*2 & 79.8 & 0.95 & Low discrimination \\
\hline \multicolumn{6}{|l|}{ ウナギ由来 } \\
\hline $362(4 / 5)$ & 7141010 & 該当分類群なし & & & \\
\hline$(1 / 5)$ & 7143400 & E. durans*2 & 96.3 & 0.75 & Low discrimination \\
\hline $363(2 / 5)$ & 5141010 & 該当分類群なし & & & \\
\hline$(2 / 5)$ & 5141110 & 該当分類群なし & & & \\
\hline$(1 / 5)$ & 5143111 & L. lactis*2 & 73.4 & 0.81 & Low discrimination \\
\hline \multicolumn{6}{|l|}{ テラピア由来 } \\
\hline \multicolumn{6}{|c|}{$629(5 / 5), 630(2 / 2), 631(1 / 1), 632(2 / 2), 633(2 / 2), 634(2 / 2)$} \\
\hline & 4163117 & 該当分類群なし & & & \\
\hline \multicolumn{6}{|l|}{ アユ由来 } \\
\hline \multicolumn{6}{|c|}{$341(5 / 5), 342(1 / 1)$} \\
\hline & 4143117 & 該当分類群なし & & & \\
\hline
\end{tabular}

*1 E., Enterococcus; G., Gemella; S., Streptococcus; L., Lactococcus

*2 インデックスには 2 3 の菌種が記載されており, 最初に記載されている菌種のみ示した。

考えられた。同様のことがブリ由来非溶血性菌にもいえ た。さらに, この菌の菌株 717 を用いた 5 回の試験中 1 回のみ数值プロファイルが異なり，S. milleri に同定 された。しかし，これはアルギニン脱水素試験の結果の 違いだけであり，この 1 回のみ弱陽性となった。本来, この菌のアルギニン脱水素反応は陰性であり ${ }^{3)}, 1$ 回の みの弱陽性は例外と考え, ブリ由来非溶血性菌の数值プ ロファイルとしては 1060000 が採用できると考えられ た。ブリ由来 $\beta$ 溶血性菌およびウナギ由来菌は同じ菌株 においても同一の数值プロファイルが得られず，使用菌 株が少なくはっきりとしたことは不明だが，これらはこ のキットでは同定できないと考えられた。以上のことか ら, 今回使用した魚類病原性連鎖球菌の菌株はアピスト レップ 20 のインデックスによる種同定はできなかった
ものの，同定に利用でき得る数值プロファイル(その值) が得られたのは，ブリ由来 $\alpha$ 溶血性菌 (5143010)，ブリ 由来非溶血性菌 (1060000), テラピア由来菌 (4163117), アユ由来菌 (4143117) であった。

\section{参考文献}

1) 楠田理一・川合研児・豊嶋利雄 - 小松 功 (1976): 日水誌，42，1345-1352，2）見奈美輝彦・中村正夫・ 池田弥生 - 尾崎久雄 (1979) : 魚病研究, 14, 15-19. 3) 飯田貴次 - 古川 清 - 酒井正博 - 若林久嗣 (1986): 魚病研究, 21，33-38，4) 楠田理一 一小松 功 (1978): 日水誌, 44, 1073-1078，5) Kitao, T., T. Aoki, and R. Sakoh (1981): Fish Path , 15, 301-307. 6) 大西 圭二・城 泰彦 (1981)：魚病研究，16, 63-67. 